\title{
Economic values for health and feed efficiency traits of dual-purpose cattle in marginal areas
}

\author{
Z. Krupová, ${ }^{* 1}$ E. Krupa, ${ }^{*}$ M. Michaličková,† M. Wolfová, ${ }^{*}$ and R. Kasardał \\ *Institute of Animal Science, PO Box 1, 10401 Prague, Czech Republic \\ †Animal Production Research Centre Nitra, National Agricultural and Food Centre, Hlohovecká 2, 95141 Lužianky, Slovakia \\ ‡Slovak University of Agriculture, Tr. A. Hlinku 2, 94976 Nitra, Slovakia
}

\section{ABSTRACT}

Economic values of clinical mastitis, claw disease, and feed efficiency traits along with 16 additional production and functional traits were estimated for the dairy population of the Slovak Pinzgau breed using a bioeconomic approach. In the cow-calf population (suckler cow population) of the same breed, the economic values of feed efficiency traits along with 15 further production and functional traits were calculated. The marginal economic values of clinical mastitis and claw disease incidence in the dairy system were $-€ 70.65$ and $-€ 26.73$ per case per cow and year, respectively. The marginal economic values for residual feed intake were $-€ 55.15$ and $-€ 54.64 / \mathrm{kg}$ of dry matter per day for cows and breeding heifers in the dairy system and $-€ 20.45,-€ 11.30$, and $-€ 6.04 / \mathrm{kg}$ of dry matter per day for cows, breeding heifers, and fattened animals in the cow-calf system, respectively, all expressed per cow and year. The sums of the relative economic values for the 2 new health traits in the dairy system and for residual feed intake across all cattle categories in both systems were 1.4 and $8 \%$, respectively. Within the dairy production system, the highest relative economic values were for milk yield (20\%), daily gain of calves (20\%), productive lifetime (10\%), and cow conception rate $(8 \%)$. In the cow-calf system, the most important traits were weight gain of calves from 120 to $210 \mathrm{~d}$ and from birth to $120 \mathrm{~d}$ (19 and 14\%, respectively), productive lifetime (17\%), and cow conception rate (13\%). Based on the calculation of economic values for traits in the dual-purpose Pinzgau breed, milk production and growth traits remain highly important in the breeding goal, but their relative importance should be adapted to new production and economic conditions. The economic importance of functional traits (especially of cow productive lifetime and fertility) was sufficiently high to make the inclusion of these traits into the breed-

Received July 28, 2015.

Accepted September 18, 2015.

${ }^{1}$ Corresponding author: krupova.zuzana@vuzv.cz ing goal necessary. An increased interest of consumers in animal welfare and quality of dairy farm products should probably lead to the incorporation of health traits (clinical mastitis incidence and somatic cells score) into the breeding goal. However, keeping carcass traits in the breeding goal of the Slovak Pinzgau breed does not seem to be relevant to the long-term market situation.

Key words: cattle, mastitis, claw disease, residual feed intake

\section{INTRODUCTION}

Functional traits of cattle (such as health, reproduction, and survival traits) and feed efficiency traits generally have substantial effect on profitability because they influence utilization of inputs in the production process (Sölkner et al., 2000; Williams et al., 2011; GonzalezRecio et al., 2014). Lower costs (mostly for veterinary and feed inputs), higher milk price and quality, health issues, and environmentally sustainable farming are also important in relation to such traits. Improving feed efficiency in cattle herds offers an opportunity to reduce the negative effects of the cattle production on the environment through lower greenhouse gas emissions and nutrient losses to the environment (Bell et al., 2013; Connor, 2015). A direct inclusion of health traits in the breeding goal is expected to bring an extra economic benefit (Sadeghi-Sefidmazgi et al., 2011). Furthermore, the noneconomic value of health traits should be taken into account, which is connected with a growing interest of consumers in socioethical aspects of animal production, such as animal welfare and product quality (Hietala et al., 2014).

Some functional traits have already been included into the breeding goals and selection schemes, and their economic values were estimated for various cattle breeds (Phocas et al., 1998; Sölkner et al., 2000; Fernández-Perea and Jiménez, 2004). To the best of our knowledge, however, economic values for claw disease incidence in dairy herds have not yet been published.

Slovak Pinzgau cattle comprise a dual-purpose breed typically farmed in mountainous regions of Slovakia. 
The breed has been registered by the Food and Agriculture Organization of the United Nations as threatened with extinction and classified as an animal genetic resource since 1994 (Kadlečík et al., 2008). Considering the actual population size, with almost 10,500 live animals and 2,860 cows registered in the herd book (ASPB, 2015), the breed contributes approximately $1 \%$ to overall milk production and the same proportion to overall beef production in Slovakia. The general aim of the breeding goal is at developing more productive dual-purpose (milk and meat) cattle suitable for mountainous regions, albeit without detailed specification of target-trait levels other than those for milk yield (5,500 to $6,500 \mathrm{~kg}$ per lactation), growth rate in fattening (1,200 to $1,300 \mathrm{~g} / \mathrm{d})$, and dressing percentage (up to 58\%; ASPB, 2015). At present, breeding values and economic values for milk carrier, milk fat, and milk protein yield of cows (Candrák and Lichanec, 2007) along with breeding values for live weight of calves at $210 \mathrm{~d}$ of age are the key breeding parameters in the Slovak Pinzgau population. Kasarda et al. (2014) developed, for the first time, a total merit index based on economic and breeding values for milk yield, productive lifetime, and live weight at $210 \mathrm{~d}$ of age for Slovak Pinzgau cattle with the aim of using the index in a simulation study. The economic values applied in that study had been calculated previously by Krupová et al. (2009) and Krupa et al. (2011). Since that time, the production and economic conditions of the breed have changed substantially and, mainly due to reasons of economic insufficiency, the population has been reduced (Kasarda et al., 2014). Moreover, economic values for health traits such as clinical mastitis and incidence of claw disease, as well as feed efficiency traits, have not previously been calculated for this breed.

The objective of the present study was to acquire information on the economic importance of the health and feed efficiency traits for a future breeding goal in Slovak Pinzgau cattle. For this purpose, the economic values for all production and functional traits are herein jointly estimated for both dairy and cow-calf populations of the breed using a complex bioeconomic model.

\section{MATERIALS AND METHODS}

\section{Basic Characteristics of Production Systems}

Economic values of traits were calculated for the Slovak Pinzgau breed farmed partially in dairy and partially in cow-calf (so-called suckler) production systems. Both production systems were treated as selfreproducing (breeding and commercial herds together), with rearing of breeding females and males for their own replacement. A classical indoor farming system with loose housing of cows, selling (exporting) of surplus calves at weaning, and selling of surplus pregnant breeding heifers was assumed for the dairy population. A traditional pasture management system with winter calving and selling (exporting) of surplus calves at autumn weaning was in use for the cow-calf population. Pasture covered the period from May 1 to October 30, and indoor feeding was used during the rest of the year. In this system, natural mating and integrated intensive indoor fattening of bulls and extensive fattening of steers were practiced. Surplus breeding heifers were sold before mating.

The structures of dairy and suckler herds in their steady state were generated using a Markov chain approach as described by Wolfová et al. (2007). The main input parameters for both dairy and cow-calf herds used in our study corresponded to the average values obtained for the Slovak Pinzgau population from our own investigations on farms and from the databases of the Breeding Service of the Slovak Republic over the 3-yr period from 2011 to 2013 (unpublished data).

\section{Profit Function}

The economic efficiency of the evaluated production systems was expressed as the present value of total profit (TP) per cow entering a reproductive cycle and per year as follows:

$$
\mathrm{TP}=\operatorname{rev}^{\prime} \times \mathrm{NDE}^{(\mathrm{rev})}-\operatorname{cost}^{\prime} \times \mathrm{NDE}^{(\text {cost })},
$$

where rev' $^{\prime}$ and cost $^{\prime}$ are row vectors of revenues and costs and $\mathrm{NDE}^{(\mathrm{rev})}$ and $\mathrm{NDE}^{\text {(cost) }}$ are column vectors of the number of discounted expressions connected with revenues and costs occurring in the individual cattle categories within the herd (Wolfová et al., 2007). An annual discount rate of $1.0 \%$ (estimated as the difference between the average annual investment rate and inflation rate valid in Slovakia in the evaluated time period) was applied to account for the delay in expression, and associated time value of money, of traits that influence revenues and costs in the life of the animal.

Revenues were derived from milk and breeding heifers sold in the dairy system, from fattened bulls and steers in the cow-calf system, and from calves sold at weaning; slaughtered cows and heifers; manure; and subsidies in both production systems. Revenues from milk were a function of milk amount, fat and protein content, and SCC. Revenues from slaughtered animals were a function of live weight at slaughter, dressing percentage, and the average price per kilogram of carcass weight, defined on the basis of the distribution of carcasses across fleshiness and fat-covering classes within the SEUROP grading system. Direct subsidies paid in 
relation to the dairy population and to cow-calf herds were included in revenues. Average values of individual subsidy payments for the period from 2011 to 2013 (MARD SR, 2014) were used. Indirect agricultural subsidies (single area payments, support for crops grown on arable land, and support for less-favored areas) were not considered, because these payments are not connected with animal performance and thus have no effect on the economic values of evaluated traits. The main input parameters for the revenues calculations in both production systems are listed in Table 1.

Costs for feeding, housing, veterinary care, breeding, as well as fixed costs (labor, energy, repairs, insurance, fuel, and overhead costs) were defined for each category of animals and considered in the model. Feeding costs were calculated on the basis of daily energy and protein requirements for maintenance, growth, milk production, pregnancy, and activity of individual animal categories and according to the average prices per kilogram of fresh matter in feeding rations with given DM, net energy, and protein contents. The equations cited by Wolf et al. (2013) were applied for those calculations. The compositions of feeding rations and prices for feed components were obtained through our own investigations on cooperating farms from 2011 to 2013 (unpublished data). Input parameters used for the calculation of feeding costs are shown in Table 2.

Breeding costs were those associated with $\mathrm{AI}$ and to keep breeding bulls for natural mating. Total fixed costs in rearing breeding animals and in fattening were assumed to depend upon the length of the fattening or rearing periods when calculating the economic values of growth traits. The basic input parameters for calculating the nonfeed costs in dairy and cow-calf systems are shown in Table 3.

Detailed data used for calculating the effect of the health traits (clinical mastitis and claw disease incidence) on the economic efficiency (i.e., to calculate economic values of these traits) of the dairy Pinzgau population are presented in Table 4 . These data were obtained through our own investigations on dairy farms from 2011 to 2013 (unpublished data) or taken from previous studies dealing with dairy cattle (Wolfová et al., 2006; Vasil', 2009; Tongel' and Brouček, 2010).

Table 1. Input parameters for calculating revenues

\begin{tabular}{|c|c|c|}
\hline \multirow[b]{2}{*}{ Variable (unit) } & \multicolumn{2}{|c|}{ Production system } \\
\hline & Dairy & Cow-calf \\
\hline Basic milk price $^{1}(€$ cents $/ \mathrm{kg})$ & 31.00 & - \\
\hline Bonus for milk protein percentage ( $€$ cents/\% of protein) & 1.2 & - \\
\hline Bonus for milk fat percentage ( $€$ cents $/ \%$ of fat) & 1.0 & - \\
\hline Price reduction for nonstandard milk $^{2}$ ( $€$ cents $/ \mathrm{kg}$ of milk) & 6.3 & - \\
\hline \multicolumn{3}{|l|}{ Average price by weight $(€ / \mathrm{kg})$} \\
\hline Calves ${ }^{3}$ & 2.66 & 2.45 \\
\hline Heifers $^{3}$ & 1.31 & 1.16 \\
\hline Cows $^{4}$ & 1.17 & 1.05 \\
\hline Fattened bulls and steers ${ }^{5}$ & - & 1.49 \\
\hline \multicolumn{3}{|l|}{ Average live weight (kg/animal) } \\
\hline Calves & 91 & 195 \\
\hline Heifers & 451 & 407 \\
\hline Cows & 540 & 540 \\
\hline Fattened bulls and steers & - & 550 \\
\hline Price for manure $(€ / 100 \mathrm{~kg})$ & 0.03 & 0.03 \\
\hline Production of manure per cow $(\mathrm{kg} / \mathrm{d})$ & 40 & 16 \\
\hline \multicolumn{3}{|l|}{ Direct subsidies $^{6}$} \\
\hline Milk production $(€ / \mathrm{kg}$ of milk) & 0.0117 & - \\
\hline Livestock unit ( $€$ per cow and year) & 88.06 & 99.50 \\
\hline Animal genetic resources ( $€$ per cow and year) & 200 & 200 \\
\hline Performance testing ( $€$ per cow and year) & 23.13 & - \\
\hline \multicolumn{3}{|c|}{$\begin{array}{l}{ }^{1} \text { Milk with SCC ranged between } 300,000 \text { and } 400,000 \text { cells } / \mathrm{mL} \text {, and fat and protein contents ranged from } 3.1 \\
\text { to } 4.2 \% \text { and from } 2.8 \text { to } 3.6 \% \text {, respectively. }\end{array}$} \\
\hline \multicolumn{3}{|c|}{${ }^{2}$ Milk with SCC $>400,000$ cells $/ \mathrm{mL}$ and for fat and for protein contents $<3.1 \%$ and $<2.8 \%$, respectively. } \\
\hline \multicolumn{3}{|c|}{$\begin{array}{l}{ }^{3} \text { Price is given per kilogram of live weight of female and male calves upon weaning at age } 100 \mathrm{~d} \text { in the dairy } \\
\text { and } 259 \mathrm{~d} \text { in the cow-calf production system and per kilogram of live weight of heifers sold pregnant at } 1,060 \\
\mathrm{~d} \text { of age in the dairy and sold before mating at } 896 \mathrm{~d} \text { of age in the cow-calf production system. }\end{array}$} \\
\hline \multicolumn{3}{|c|}{${ }^{4}$ Price is given per kilogram of live weight for culled cows. } \\
\hline \multicolumn{3}{|c|}{$\begin{array}{l}{ }^{5} \text { Price is given per kilogram of carcass weight based on the distribution of carcasses across the SEUROP classes } \\
\text { for fleshiness and fat covering. Bulls and steers were slaughtered at average ages of } 598 \text { and } 706 \mathrm{~d} \text {, respectively. } \\
{ }^{6} \text { Average value of direct subsidies during } 2011 \text { to } 2013 \text {. Subsidies for performance testing included subsidies } \\
\text { for all cattle categories in the herd (calves to } 6 \text { mo, cattle from } 6 \text { to } 24 \text { mo, and bulls and heifers up to } 24 \text { mo } \\
\text { taken as } 0.2,0.6 \text {, and } 1.0 \text { livestock units, respectively). }\end{array}$} \\
\hline
\end{tabular}


Table 2. Input parameters for calculating feeding costs of animal categories

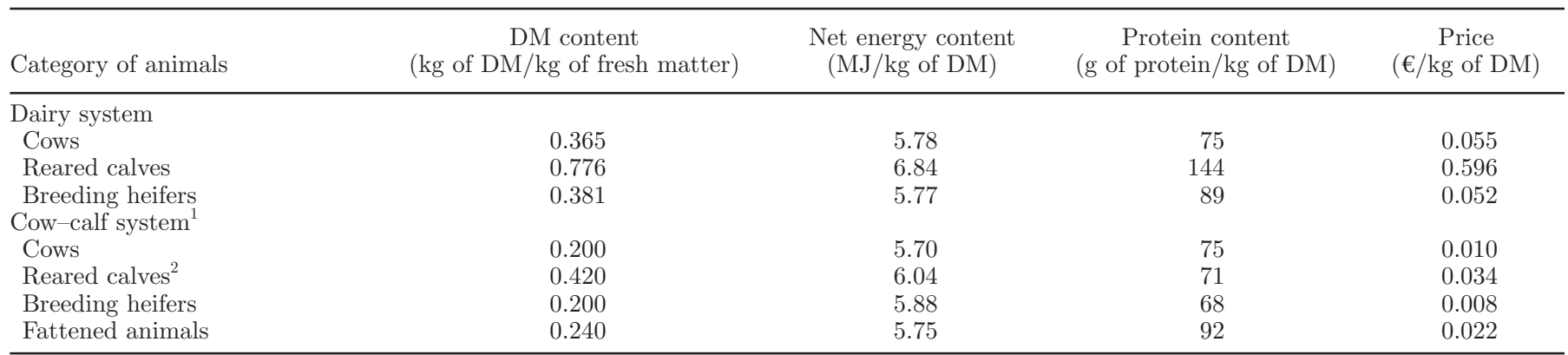

${ }^{1}$ Expressed for example feeding ration used in summer.

${ }^{2}$ Values apply only in case of supplementary feeding (in addition to pasture, which makes up most of the diet) and with no consideration given to milk consumed.

\section{Calculation of Economic Values}

The marginal economic value (economic importance) of trait $l\left(\mathrm{ev}_{l}\right)$ was calculated as the partial derivative of the profit function with respect to that trait:

$$
\mathrm{ev}_{l}=\left.\frac{\partial \mathrm{TP}}{\partial \mathrm{TV}_{l}}\right|_{\mathrm{TV}_{l}=\mathrm{TV}_{\mathrm{av}}}
$$

where TP is total profit per cow and year as defined above, $\mathrm{TV}_{l}$ is the value of trait $l$, and $\mathrm{TV}_{l_{\mathrm{av}}}$ is the trait mean within the population. In the calculation, the partial derivative was approximated by the difference quotient. The difference was set to $\pm 0.5 \%$ of the trait mean (Wolfová et al., 2007). Economic values were calculated separately for the dairy and the cow-calf populations using complexes of milk production, functional (reproduction, health), growth, carcass, and feed efficiency traits. An overview of the evaluated traits and their mean values (averaged over the period from 2011 to 2013) for the dairy and cow-calf systems is presented in Table 5. Detailed definitions for most traits and assumptions made for the calculation of their economic

Table 3. Input parameters for calculating other costs

\begin{tabular}{|c|c|c|}
\hline \multirow[b]{2}{*}{ Variable (unit) } & \multicolumn{2}{|c|}{ Production system } \\
\hline & Dairy & Cow-calf \\
\hline Price of semen for AI ( $€$ per insemination dose) & 8.00 & - \\
\hline Average number of inseminations per heifer, per cow & $1.8,2.5$ & - \\
\hline Number of reinseminations & 1 & - \\
\hline Number of cows per breeding bull & - & 35 \\
\hline \multicolumn{3}{|l|}{ Costs for removing dead animals ( $€$ per animal) } \\
\hline Mature animals & 307 & 307 \\
\hline Young animals & 183 & 183 \\
\hline \multicolumn{3}{|l|}{ Costs for veterinary care ${ }^{1}$} \\
\hline Cows $(€$ per animal per reproductive cycle) & 97.20 & 87.40 \\
\hline Reared calves ( $€$ per animal in rearing) & 3.60 & - \\
\hline Breeding heifers ( $€$ per animal to calving) & 34.60 & 15.00 \\
\hline Fattened bulls and steers ( $€$ per animal) & - & 18.00 \\
\hline \multicolumn{3}{|l|}{ Cost for dystocia ${ }^{2}$ ( $€$ per calving) } \\
\hline Calving score 3 & 33.20 & 33.20 \\
\hline Calving score 4 & 116.20 & 116.20 \\
\hline Dystocia incidence (cases per 100 calvings) & 3.2 & 3.0 \\
\hline \multicolumn{3}{|l|}{ Fixed $\operatorname{costs}^{3}$ ( $€$ per animal per day) } \\
\hline Cows & 2.32 & 1.02 \\
\hline Reared calves & 0.66 & - \\
\hline Breeding heifers & 0.48 & 0.63 \\
\hline Fattened bulls and steers & - & 0.53 \\
\hline Cost for water $(€ / d)$ & 0.090 & 0.090 \\
\hline Cost for straw for bedding for cows $(€ / d)$ & 0.049 & 0.035 \\
\hline
\end{tabular}


values can be found in Wolfová et al. (2007), Krupová et al. (2009), and Krupa et al. (2011). Therefore, only the approach used in calculating the economic value for claw disease incidence in dairy herds will be described here in detail followed by a short description of the other traits.

Claw disease incidence was defined as the number of claw disease cases per cow and year at risk in the herd, averaged over all lactations. The days when cows were affected by disease were not included in the total number of days at risk. Sick animals from routine trimmings were included in calculating claw disease incidence only in the case where additional costs were connected with those animals (e.g., for special drugs), because the routine trimmings were included in fixed management costs. Claw disease incidence included all cases of claw diseases, including both those treated with and without antibiotics. Different claw diseases were included, for example, interdigital dermatitis, heel horn erosion, digital dermatitis, and sole ulcer. The latter 2 represent a dominant part of the total incidence of claw diseases in Slovak Pinzgau herds (Riecka et al., 2008). Effect of claw disease on the loss of revenue due to discarding of milk during cow illness (only for cases treated with antibiotics) as well as additional costs for drugs, veterinary service, and labor for herdsmen's or trimmers' time were considered when calculating the marginal economic value for the trait. To avoid double counting of effects, the effect of claw disease on other traits included simultaneously in the evaluation (milk yield, reproductive traits, cow survival) was not considered when calculating financial losses from claw disease. The amount of discarded milk (Disc $c_{\text {milk }}$ ) in kilograms per cow per year was calculated as

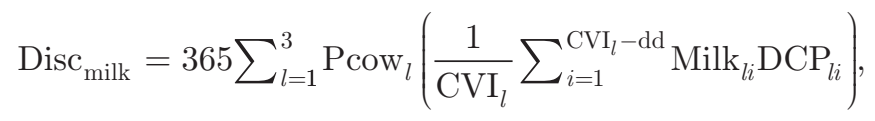

where $\mathrm{Pcow}_{l}$ is the proportion of cows in lactation $l$ ( $l$ $=1,2$, or $\geq 3), \mathrm{CVI}_{l}$ is the calving interval in lactation $l$ (days), Milk ${ }_{l i}$ is the milk yield $(\mathrm{kg} / \mathrm{d})$ on day $i$ of lactation $l, \mathrm{DCP}_{l i}$ is the prevalence of claw disease treated with antibiotics on day $i$ of lactation $l$. This prevalence is calculated as the number of affected cows (meaning their milk must be discarded) at day $i$ of lactation $l$ divided by the number of cows at day $i$ of lactation $l$. Lactation length is calculated as the difference between the calving interval and days dry (dd).

Clinical mastitis incidence was defined as the number of clinical mastitis cases per cow and year at risk. In calculating the economic value for this trait, a similar procedure to that described for claw disease incidence was used (for details see Wolfová et al., 2006).

The procedure applied for calculating economic values for residual feed intake (RFI) can be found in Hietala et al. (2014). Residual feed intake was defined as the difference between the actual daily DMI and the predicted daily DMI of an animal. Based on the definition of RFI (Williams et al., 2011), the average RFI of each animal group of interest (cows, breeding heifers, fattened animals) was assumed to be zero, which means the actual daily DMI was equal to the predicted daily DMI in the base calculation. Therefore, the procedure for the estimation of economic values of traits described before cannot be applied for RFI. To calculate the economic value for RFI, the trait mean for the appropriate animal group was changed by $\pm 0.05 \mathrm{~kg}$ of $\mathrm{DM} / \mathrm{d}$.

Table 4. Detailed parameters for calculating economic values of claw disease and clinical mastitis incidence

\begin{tabular}{|c|c|}
\hline Variable (unit) & Value \\
\hline \multicolumn{2}{|l|}{ Parameters for claw disease } \\
\hline & Costs for drugs or treatment ( $€ /$ case $)$ \\
\hline Time of veterinarian service (h/case) & 0.50 \\
\hline Charge for veterinary service $(€ / h)$ & 9.21 \\
\hline Number of cases per cow-year at risk (minimum $/$ maximum $)^{1}$ & $0.20 / 0.40$ \\
\hline \multicolumn{2}{|l|}{ Parameters for clinical mastitis } \\
\hline Costs for drugs $(€ /$ case $)$ & 27.82 \\
\hline Time of veterinarian service (h/case) & 0.50 \\
\hline Charge for veterinary service $(€ / h)$ & 9.21 \\
\hline Number of cases per cow-year at risk (minimum/maximum $)^{1}$ & $0.20 / 0.30$ \\
\hline Price of drugs for dry-cow treatment $(€ /$ dose $)$ & 1.22 \\
\hline Percentage of cows receiving dry-cow antibiotics & 97 \\
\hline
\end{tabular}


Table 5. Means and genetic SD (GSD) of traits

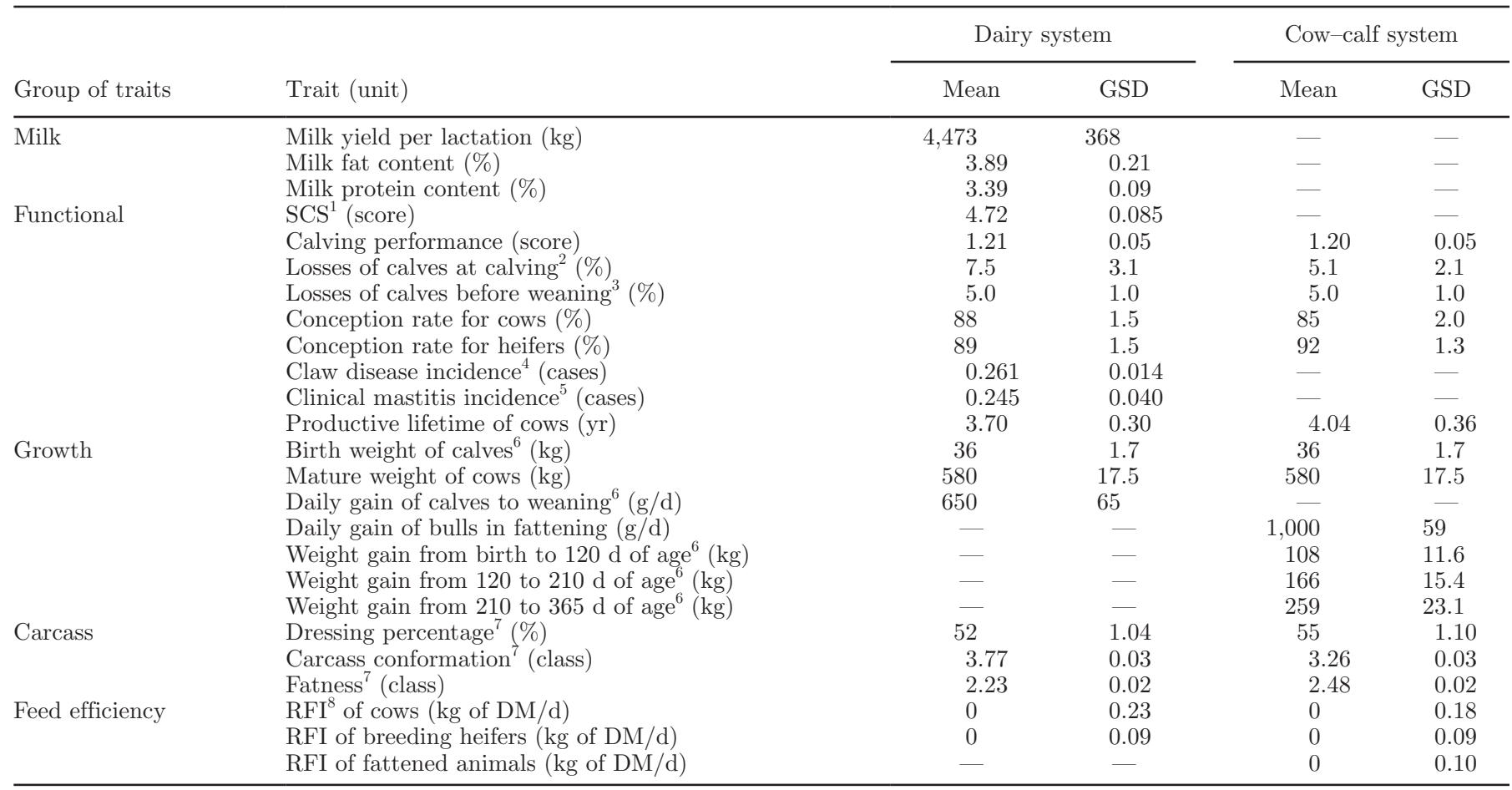

${ }^{1}$ Somatic cell score calculated as $\log _{2}(\mathrm{SCC} / 100,000)+3$.

${ }^{2}$ Losses of calves at calving include aborts, calves born dead, and calves that died within $48 \mathrm{~h}$ after calving.

${ }^{3}$ Losses of calves to weaning are expressed as proportion of calves born alive. Age of calves at weaning was 100 and $259 \mathrm{~d}$ in dairy and cow-calf systems, respectively.

${ }^{4}$ Claw disease incidence expressed as the number of claw disease cases per cow-year at risk, averaged over all lactations.

${ }^{5}$ Clinical mastitis incidence expressed as the number of clinical mastitis cases per cow-year at risk, averaged over all lactations.

${ }^{6}$ Average values for female and male progeny.

${ }^{7}$ The means of the carcass traits are given for heifers slaughtered during the rearing period in the dairy system and for fattened bulls in the cow-calf system.

${ }^{8}$ Residual feed intake.

When deriving the economic values for categorical traits (calving score, carcass conformation, and fatness classes), an underlying normal distribution was assumed and the approach described by Wolfová et al. (1995) was used. Carcass conformation and fatness classes were calculated based upon the distribution of carcasses across the SEUROP classes for fleshiness and fat covering. Calving score was calculated based upon the distribution of calvings in the 4 score groups, which were (1) easy calving without help, (2) easy calving with help, (3) difficult calving with veterinary assistance, and (4) calving with caesarean section.

The definition of SCS was based on a logarithmic transformation of the average number of somatic cells per milliliter of milk. Milk yield was defined as 305-d milk yield with constant fat and protein content averaged over all lactations. Productive lifetime of cows was calculated as the average time period from the first calving to death or culling.
To compare the economic importance of different traits, the relative economic values of traits were calculated as follows:

$$
\operatorname{evr}_{l}=100 \times\left[\left|\operatorname{evs}_{l}\right| /\left(\Sigma_{l}\left|\operatorname{evs}_{l}\right|\right)\right],
$$

where $\mathrm{evr}_{l}$ is the relative economic value of trait $l$ in percent and $\mid$ evs $_{l} \mid$ is the absolute value of the standardized marginal economic value (i.e., marginal economic value times the genetic standard deviation) of trait $l$. Genetic standard deviations used for standardizing the marginal economic values (see Table 5) were obtained from analysis of the databases of the Breeding Service of the Slovak Republic (from 2011 to 2013, unpublished data), or taken from literature sources cited by Wolfová et al. (2006, 2007) and Krupa et al. (2011) when relevant data for Slovak Pinzgau cattle were not available. This was the case for RFI where the genetic standard deviation was not known and was therefore estimated 


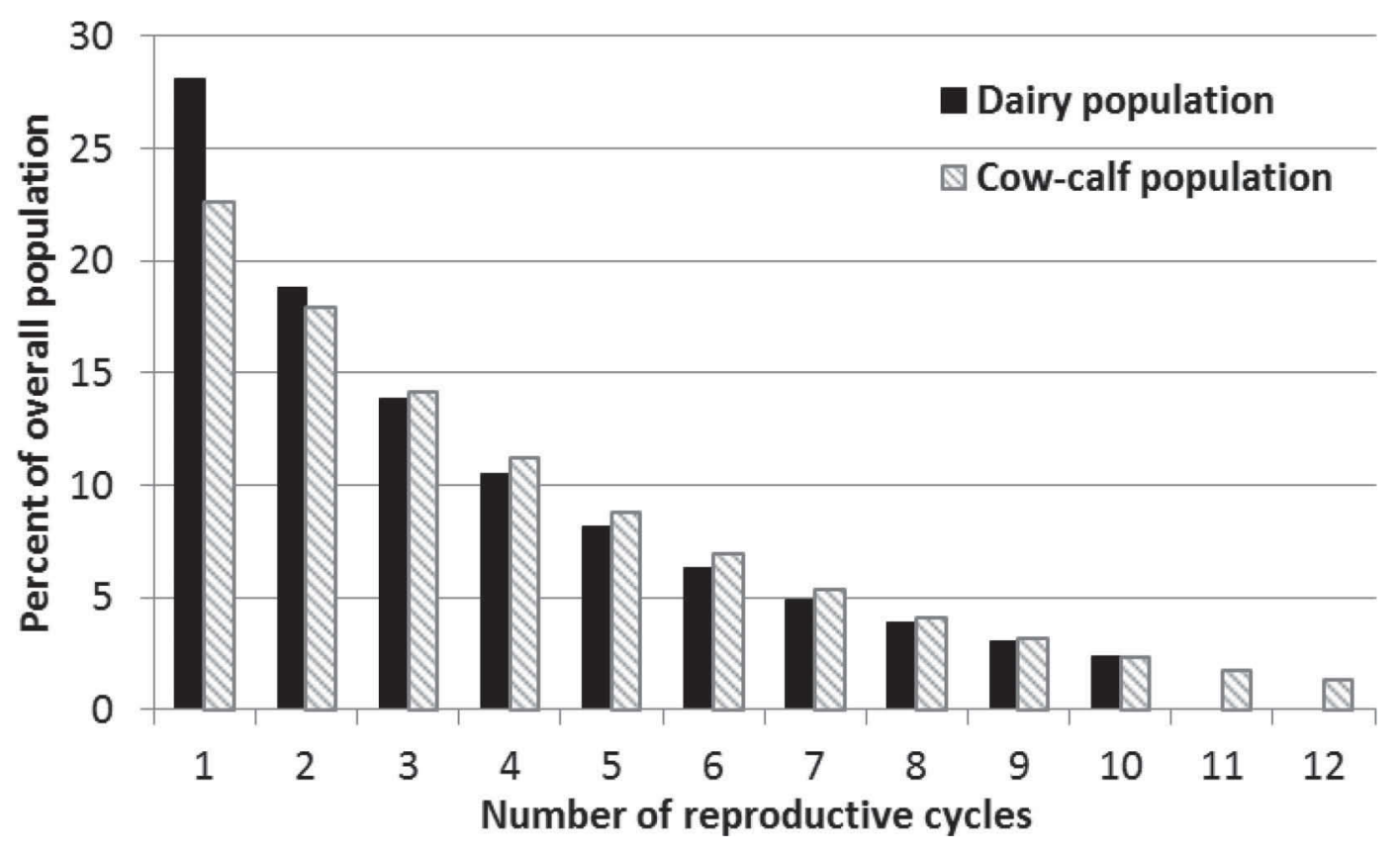

Figure 1. Structures of Slovak Pinzgau cow herds in dairy and cow-calf production systems.

from the mean of the daily DMI of the corresponding animal category, the phenotypic coefficient of variation, and the heritability for RFI given in the literature (Veerkamp et al., 1995; Williams et al., 2011).

The programs EWDC (version 3.0.4) and EWBC (version 2.2.3), both from the Ecoweight 6.0.4 program package (Wolf et al., 2013), were used in calculating economic values in the Pinzgau dairy and cow-calf populations, respectively.

\section{RESULTS}

The age structures that were determined for the herds in both dairy and cow-calf populations of Slovak Pinzgau cattle are shown in Figure 1. The average productive lifetime of cows was $3.70 \mathrm{yr}$ in the dairy and $4.04 \mathrm{yr}$ in the cow-calf populations. The survival and use or sale of offspring for both modeled production systems are described in Table 6. In the dairy population, almost 32 breeding heifers were reared for replacement per 100 cows per year, which means only 3 surplus heifers were available for sale. In the cow-calf population, about 27 heifers per 100 cows were reared for replacement annually and 18 breeding heifers could be sold. The highest proportions of surplus male calves were sold at weaning (at ages 3 and 8 mo in the dairy and cow-calf systems, respectively), and only a few bulls and steers were fattened in the cow-calf production system.

Considering the basic economic characteristics for the modeled production systems, revenues from milk
( $€ 1,259$ per cow and year) and from weaned calves (€84 per cow and year) made up $91 \%$ of total revenues in the dairy system. In the cow-calf system, revenues from weaned calves ( $€ 161$ per cow and year) comprised $50 \%$, revenues from fattened animals (€47 per cow and year) $15 \%$, and other revenues (sold breeding animals, culled cows, and manure) $35 \%$ of total revenues. Even when including direct subsidies, production was economically unprofitable in both systems under the given production and economic conditions $(-€ 457$ and $-€ 449$ per cow and year, respectively). Positive profit and profitability ratios could be expected in these systems if indirect subsidies were included in the calculation.

The marginal economic values calculated for 20 and 18 traits in the dairy and cow-calf production systems, respectively, are listed in Table 7. Of those traits evaluated in both production systems, calving performance, conception rate of females (cows and heifers), and cow productive lifetime were evidently more important in the dairy system than in the cow-calf system. For instance, an increase in cow conception rate by one percentage point raised the profit per cow and year by $€ 11.6$ in the dairy system but by just $€ 4.5$ in cow-calf herds. The negative economic values for SCS, losses of calves, RFI, carcass conformation, fatness classes, and health traits showed that increases in the means of these traits are economically unfavorable.

The relative economic values of the traits of the Slovak Pinzgau breed for both production systems also are summarized in Table 7 . These values enable comparison of the economic importance of all traits within each 
Table 6. Survival and use or sale of offspring in 2 production systems (number of animals/100 calvings)

\begin{tabular}{lcc}
\hline & \multicolumn{2}{c}{ Production system } \\
\cline { 2 - 3 } Category & Dairy & Cow-calf \\
\hline Calves born alive $_{\text {Calves weaned }}{ }^{2}$ & 94.2 & 96.0 \\
Calves sold at weaning $_{\text {Male calves sold for breeding }}$ & 88.6 & 89.7 \\
Bulls or steers fattened to target slaughter weight $_{\text {Heifers reared for replacement }}$ & 42.6 & 31.3 \\
Heifers sold before mating & 1.9 & 1.1 \\
Heifers sold pregnant & 31.6 & $9.6 / 1.0$ \\
\hline
\end{tabular}

${ }^{1}$ Age of calves at weaning was $100 \mathrm{~d}$ in dairy and $259 \mathrm{~d}$ in cow-calf systems.

production system. The highest relative importance was found for daily gain of calves to weaning (until the age of $100 \mathrm{~d}$ in the dairy population), weight gain of calves from 120 to $210 \mathrm{~d}$ (in the cow-calf population), and milk yield (in the dairy population), which contributed $20.3,19.3$, and $20.3 \%$, respectively, to the sum of the absolute values of the standardized economic values over all traits within each system. High relative economic importance in the dairy population was further determined for cow productive lifetime (10\%), SCS
(9\%), and cow conception rate $(7.7 \%)$. In the cow-calf population, the next most important traits after weight gain of calves from 120 to $210 \mathrm{~d}$ were cow productive lifetime (16.8\%), weight gain of calves to $120 \mathrm{~d}$ of age $(14.4 \%)$, and cow conception rate $(12.9 \%)$.

The high relative economic importance of the growth and functional trait complexes is also evident from Figure 2. These contribute 90 and $64 \%$ to the sum of the absolute values of the standardized economic values across all traits in the cow-calf and dairy production

Table 7. Marginal economic values (in $€$ per unit of trait and per cow and year) and relative economic values ${ }^{1}$ (\%) for traits in dairy and cow-calf production systems

\begin{tabular}{|c|c|c|c|c|}
\hline \multirow[b]{2}{*}{ Trait (unit) } & \multicolumn{2}{|c|}{ Marginal value } & \multicolumn{2}{|c|}{ Relative value } \\
\hline & Dairy & Cow-calf & Dairy & Cow-calf \\
\hline Milk yield $^{2}(\mathrm{~kg})$ & 0.124 & - & 20.2 & - \\
\hline Milk fat content (\%) & 29.47 & - & 2.7 & - \\
\hline Milk protein content (\%) & 92.71 & - & 3.7 & - \\
\hline SCS (score) & -241.05 & - & 9.1 & - \\
\hline Calving performance (score) & -156.69 & -49.20 & 3.5 & 3.5 \\
\hline Losses of calves at calving (\%) & -0.586 & -2.009 & 0.8 & 6.0 \\
\hline Losses of calves before weaning (\%) & -0.459 & -2.078 & 0.2 & 3.0 \\
\hline Conception rate of cows (\%) & 11.64 & 4.505 & 7.7 & 12.9 \\
\hline Conception rate of heifers $(\%)$ & 2.92 & 1.046 & 1.9 & 1.9 \\
\hline Claw disease incidence (cases) & -26.73 & - & 0.2 & - \\
\hline Clinical mastitis incidence (cases) & -70.65 & - & 1.2 & - \\
\hline Productive lifetime of cows (yr) & 76.40 & 32.84 & 10.1 & 16.8 \\
\hline Birth weight of calves $(\mathrm{kg})$ & 0.520 & 0.526 & 0.4 & 1.3 \\
\hline Mature weight of cows (kg) & -1.19 & -0.247 & 9.2 & 6.2 \\
\hline Daily gain of calves to weaning $(\mathrm{g} / \mathrm{d})$ & 0.705 & - & 20.3 & - \\
\hline Daily gain of bulls in fattening $(\mathrm{g} / \mathrm{d})$ & - & 0.053 & - & 4.4 \\
\hline Weight gain from birth to $120 \mathrm{~d}$ of age $(\mathrm{kg})$ & - & 0.873 & - & 14.4 \\
\hline Weight gain from 120 to $210 \mathrm{~d}$ of age $(\mathrm{kg})$ & - & 0.877 & - & 19.3 \\
\hline Weight gain from 210 to $365 \mathrm{~d}$ of age $(\mathrm{kg})$ & - & 0.013 & - & 0.4 \\
\hline Dressing percentage (\%) & 1.79 & 1.141 & 0.8 & 1.8 \\
\hline Carcass conformation (class) & -14.86 & -7.10 & 0.2 & 0.3 \\
\hline Fatness (class) & -4.46 & -6.80 & 0.0 & 0.2 \\
\hline $\mathrm{RFI}^{3}$ of cows $(\mathrm{kg}$ of $\mathrm{DM} / \mathrm{d})$ & -55.15 & -20.45 & 5.6 & 5.3 \\
\hline RFI of breeding heifers ( $\mathrm{kg}$ of $\mathrm{DM} / \mathrm{d}$ ) & -54.64 & -11.30 & 2.2 & 1.4 \\
\hline RFI of fattened animals ( $\mathrm{kg}$ of DM/d) & - & -6.04 & - & 0.9 \\
\hline Total & - & - & 100.0 & 100.0 \\
\hline
\end{tabular}

${ }^{1}$ Relative economic value is the standardized economic value (marginal economic value multiplied by the genetic SD) of a trait expressed as percentage of the sum of standardized economic values of all traits within a production system.

${ }^{2}$ Milk with average fat and protein content (see Table 5).

${ }^{3}$ Residual feed intake. 
systems, respectively. The great importance of growth traits in calves within both systems can mainly be explained by the high number of calves sold (exported) after weaning for relatively high prices (see Tables 1 and 6). No animals were fattened in the dairy system, and only about $11 \%$ of calves were fattened in the cowcalf system.

Low relative economic importance was found for the 2 health traits in the dairy system (i.e., clinical mastitis and claw disease at 1.2 and $0.2 \%$, respectively). One must take into account that the marginal economic values of these health traits do not include their effects on milk yield, cow survival, and reproduction.

The relative economic value of feed efficiency traits ranged from $0.9 \%$ (RFI of fattened animals in the cow-calf system) to $5.6 \%$ (RFI of cows in the dairy system). Summed across all animal categories, the feed efficiency traits contributed $8 \%$ to the total relative economic importance of all traits (see Figure 2) in both the dairy and cow-calf production systems. Carcass traits contributed only $1 \%$ (dairy system) or $2 \%$ (cow-calf system) to the total relative importance of all traits. This was due to the low number of slaughtered animals, low prices per kilogram of carcass weight, and small differences among carcass conformation and fatness classes (not shown in tables). Summing up the relative economic values within each of the 5 trait complexes, the relative economic values for the milk production, functional, growth, carcass, and feed efficiency traits were $27,34,30,1$, and $8 \%$ in the dairy population and $0,44,46,2$, and $8 \%$ in the cow-calf population of the Slovak Pinzgau breed (Figure 2).

\section{DISCUSSION}

\section{Economic Importance of Traits in the Slovak Pinzgau Breed}

Marginal and relative economic values calculated for most of the traits evaluated in this study generally confirmed the results of earlier studies for the Slovak Pinzgau breed (Krupa et al., 2011). However, changes in the economic and production circumstances since the time of earlier studies and the inclusion of new traits into the simultaneous estimation of economic values ( 5 new traits in the dairy and 7 in the cow-calf system) resulted in some differences in the absolute, and even more so in the relative, economic importance of traits. The inclusion of health traits increased the effect of functional traits in the dairy system, and the inclusion of feed efficiency traits diminished the relative importance of other trait complexes in both systems. Bringing milk subsidies into the calculation strength-
(A)

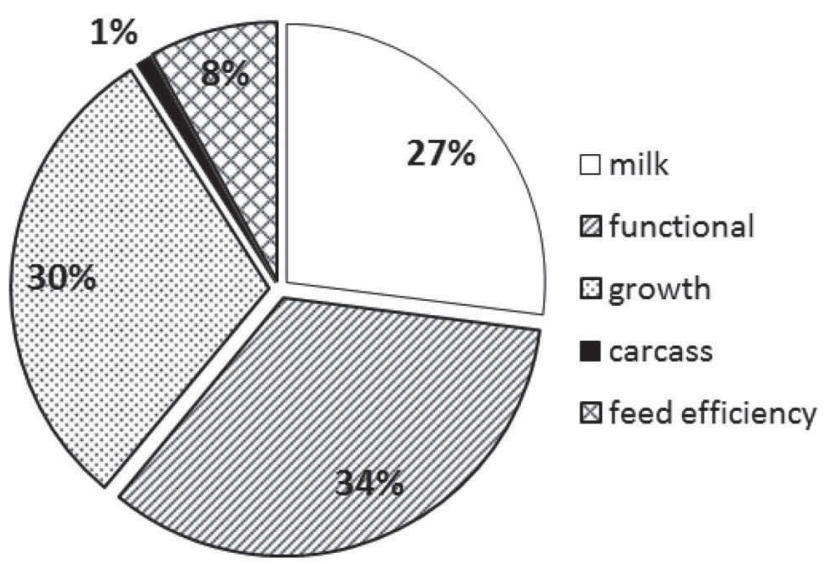

(B)

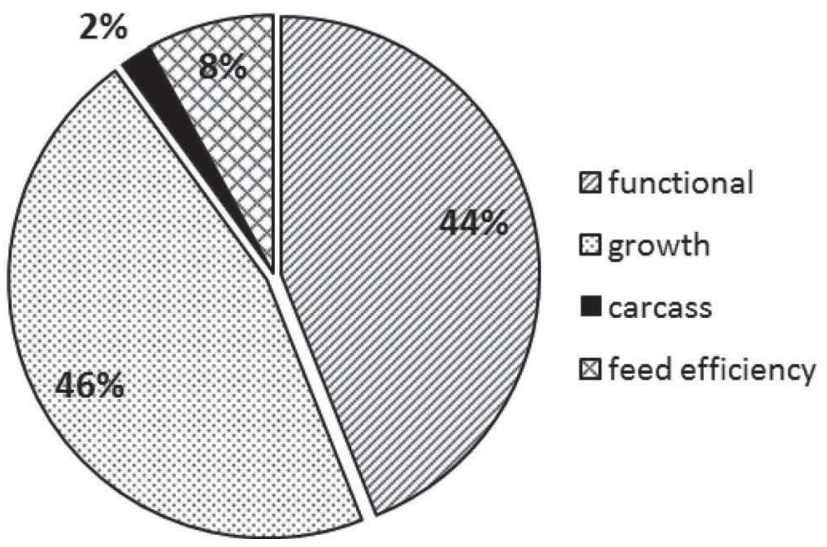

Figure 2. Relative economic importance of 5 trait complexes (milk production, functional, growth, carcass, and feed efficiency traits) in the overall breeding objective for the (A) dairy and (B) cow-calf production systems of Slovak Pinzgau cattle.

ened the relative importance of milk production traits in the dairy system. Finally, the relative values of the milk production, functional, and carcass traits were slightly lower than were those estimated by Krupa et al. (2011) in favor of growth (+10 percentage points) and feed efficiency $(+8$ percentage points) traits in the dairy Pinzgau population. Similarly, adding RFI into the evaluation of traits in the cow-calf Pinzgau population lowered the relative importance of growth traits by 9 percentage points. Generally, it can be stated that the inclusion of any additional traits to a selection index (positively or antagonistically correlated with existing traits in the index) will reduce the relative importance (or progress made) in the existing traits in the index. However, to avoid double counting, the relationship among evaluated traits has not been taken into account when their marginal and relative economic values were 
calculated. For this reason, the comparison of economic importance of traits based alone on the revenues may be misleading. A methodology that can be used to objectively compare alternative breeding objectives and selection indexes has been presented by Santos et al. (2015) with an example calculation for sheep in New Zealand and Ireland. A further study is therefore necessary to estimate responses in all traits that could be included in the breeding goal for Pinzgau cattle.

Comparison of economic values calculated in our study with those derived from different studies for other cattle breeds is difficult due to differences in trait definition, methods used for deriving marginal economic values, and management systems. Nevertheless, some general comparisons can still be made. These are presented in the following paragraphs with emphasis on the new traits included into the calculation for Pinzgau cattle.

\section{Health Traits}

The negative economic value of clinical mastitis ( $€ 70.65$ per case per cow and year) found in our study for Pinzgau cattle is comparable with values published in the literature and which ranged from $-€ 61$ to $-€ 80$ per case per cow and year (Wolfová et al., 2006; Komlósi et al., 2010; Sadeghi-Sefidmazgi et al., 2011). The markedly greater value of $-€ 389$ per case per cow and year found by Hietala et al. (2014) was mainly due to the substantially higher milk yield ( 8,800 vs. $4,400 \mathrm{~kg}$ per 305-d lactation), the higher charge for veterinary service (€160 vs. $€ 9$ per clinical mastitis case), and the higher milk price (41.7 vs. 31.0 cents $/ \mathrm{kg}$ of milk) for Finnish Ayrshire cattle compared with those in Slovak Pinzgau cattle. These results are in accordance with the paper of Sadeghi-Sefidmazgi et al. (2011), where the milk price along with the milk production level were also found to be important factors influencing the economic value of clinical mastitis.

The incidence of clinical mastitis in Slovak Pinzgau cattle obtained in our study was about 0.24 cases per dairy cow and year, which was about twice that in Finnish Ayrshire cattle (0.11; Hietala et al., 2014). In addition, the proportions of subclinical and latent forms of mastitis in Slovak dairy herds are relatively high (22 and 28\%, respectively), and altogether, $74 \%$ of the cows were found to be mastitis positive (results estimated from a clinical examination and NK-test evaluation; Vasil', 2009). Subclinical mastitis is characterized mainly by SCS. Its average value in Slovak dairy Pinzgau (4.72) is also almost twice that of Finnish Ayrshire cattle (2.6; Hietala et al., 2014). Selection against mastitis in the Scandinavian countries for many years has certainly contributed to the lower prevalence of clinical and subclinical mastitis among dairy cattle breeds in these countries.

Somatic cell count has for many years been routinely recorded and included in the breeding goals and selection schemes for dairy cattle (Sölkner et al., 2000; Pedersen et al., 2008; Zavadilová et al., 2011), but clinical mastitis has rarely been included (Mark et al., 2002). Clinical mastitis cases are recorded on most Slovak dairy farms and could be used for breeding-value estimation and in selecting for udder health, as stated by Wolf et al. (2010). In our study, the relative economic importance for the 2 traits together was $10.3 \%$ of the total economic importance of all evaluated traits in Slovak Pinzgau. Taking into account the appropriate (negative) relationships between these traits and milk yield, cow survival rate, and reproduction when constructing a selection index, the relative importance of these health traits in the index could be increased substantially.

For the third health trait, incidence of claw disease, a very low relative economic value $(0.2 \%)$ was calculated in our study. This corresponds to the good health status of the Slovak Pinzgau breed as it is farmed in extensive conditions with regular access to pasture. Also for this health trait, negative correlations with milk, fat, and protein yield have been reported in Pinzgau dairy cows (Riecka et al., 2008). Again, the mentioned relationship has not been taken into account in calculating the economic value for claw disease so as to avoid double counting.

\section{Productive Lifetime and Reproductive Traits}

After the health traits, when considering the economic values of additional functional traits evaluated in the 2 production systems, high relative economic values (10.1 and $16.8 \%$, respectively) were calculated for productive lifetime of dairy and suckler cows. This trait was the second most important in the cow-calf population and third most important in the dairy Pinzgau population. Similar results had been obtained for productive lifetime in Czech Holstein and Fleckvieh (Wolfová et al., 2007) and in Hungarian Holstein-Friesian cattle (Komlósi et al., 2010), although the relative economic values in those breeds were about twice those obtained in our study for Pinzgau cattle. In Finnish dairy cattle, on the other hand, the relative economic importance of cow productive lifetime reached no more than $6 \%$. It should be noted here that in all of the studies mentioned, the change in cow productive lifetime was achieved through changes in cow mortality and culling (for health problems) rates that caused changes in the age structure of cow herds. This made the economic value of cow productive lifetime strongly sensitive to the relation- 
ships between revenues and costs and to the current mean value of the considered trait.

Cow conception rate was a further important functional trait in our study. Its relative economic importance of $8 \%$ (in the dairy population) and $13 \%$ (in the cow-calf population) is in accordance with the values obtained by several other authors. For example, Komlósi et al. (2010) published a relative economic value of $9 \%$ for this trait in Holstein dairy cattle. Relative economic values of 3 to $9 \%$ for calving interval (which is an alternative expression of conception rate) have been estimated in dairy (Hietala et al., 2014) and beef cattle (Phocas et al., 1998) herds. In contrast, Keller et al. (2009) calculated even higher relative economic importance of cow conception rate (30\%) among all of those traits analyzed in a beef production system.

Functional traits are not included in the current breeding goal and selection index for Pinzgau cattle. Considering the economic values calculated for functional traits in our study (mainly those for the productive lifetime, cow conception rate, and udder health traits), the inclusion of these traits into the breeding program would be beneficial. Experience in Nordic countries, where for many years substantial weight has been placed on functional traits in dairy cattle, shows that selection for functional traits can be successful (Pedersen et al., 2008). In other countries, too, functional traits have already been established in selection indices of different breeds (Sölkner et al., 2000; Fernández-Perea and Jiménez, 2004).

\section{Feed-Efficiency Traits}

The economic values for RFI calculated in this study (negative values for increased RFI) confirm the positive effect of higher feed efficiency on profit in the dairy and cow-calf systems. The marginal economic value for RFI in Pinzgau dairy cows (-€55.2/ kg of DM per day per cow per year) corresponds well with that estimated for Finnish dairy cows $(-€ 55.8 / \mathrm{kg}$ of DM per day per cow per year; Hietala et al., 2014). The marginal economic value for RFI of animals in fattening estimated by those authors (-€29.5) was higher than that in our study (-€6.0), which was caused by the greater number of fattened animals per cow per year (55 animals vs. 11 animals per 100 cows). The opposite is true for RFI of breeding heifers in the dairy system ( $€ 25.5$ for Finnish dairy cows and -€54.6 for Slovak Pinzgau cattle). Summing the relative economic values of RFI across all animal categories, the relative importance of RFI reached $8 \%$ of the economic importance of all traits evaluated in Slovak dairy or cow-calf Pinzgau cattle. That is close to the values of 6 to $8 \%$ estimated for Finnish dairy cattle (Hietala et al., 2014).
As stated by Hietala et al. (2014), the economic importance of RFI in cattle is likely to grow with increasing requirements to mitigate the environmental impacts of livestock production, and particularly of intensive dairy farms. de Haas et al. (2011) estimated a negative (favorable) correlation between the estimated breeding value of sires for RFI and daughter predicted methane production. Also Bell et al. (2013) found that improving feed efficiency traits, next to health and fertility traits, can substantially reduce greenhouse gas emissions.

A further factor that can influence the effect of RFI on production costs is a rise in feed costs connected with improved milk yield in cows. This effect cannot be expected for Pinzgau cattle, however, which are used extensively in marginal mountainous areas. Furthermore, it should be taken into account that including RFI into a selection program must necessarily be accompanied by a costly test period for feed efficiency. Some challenges and possibilities for selecting for RFI in dairy cattle, such as the limited availability of individual feed intake data due to costs associated with its collection and a lack of accurate estimates of the genetic relationships between RFI and other breeding goal traits to better predict the consequence of selection, have been recently summarized by Connor (2015). This review suggests that genomic selection for reduced RFI in dairy cattle might provide the most practical approach to improve feed efficiency if proven that this method has sufficient accuracy. This is because it eliminated the need to collect phenotypical values on each animal in the target population. However, as stated by Gonzalez-Recio et al. (2014), genetic progress may be also achieved with traditional selection methods. The latter authors found that the inclusion of RFI for growing heifers in the Australian Profit Ranking index could increase the annual genetic gain of farm profitability by $3 \%$ despite an antagonism between RFI and calving interval. They stated that including RFI as part of a multitrait selection index is the obvious way to achieve optimal responses to selection in all traits of economic importance while avoiding unfavorable responses to selection that may arise as a consequence of selecting on RFI independently.

\section{Production Traits}

In the dairy Pinzgau population, the highest relative economic values were obtained for milk yield and growth rate of calves ( $20 \%$ for both). The weight gain of calves until 210 d of age (i.e., also a growth trait) in the cow-calf Pinzgau population showed a similar relative economic importance (19\%). This fact has been reflected already in the present selection criteria for the 
entire Pinzgau breed that include milk, fat, and protein yield from the dairy production system and weight of calves at $210 \mathrm{~d}$ of age from the cow-calf production system. In a high-producing dairy cattle breed, however, a higher relative economic importance has generally been obtained for milk yield (25 to $40 \%$ ) and a much lower importance for growth traits (no more than 5\%) than in our study (Komlósi et al., 2010; Hietala et al., 2014).

The ratio of the marginal economic values for milk fat and protein content (1:3.1) obtained in our study is comparable to those from some other recent European studies, where it ranged from 1:2.2 to 1:3.7 (Wolfová et al., 2007; Komlósi et al., 2010; Hietala et al., 2014). The absolute economic values of milk production traits nevertheless differed notably in the literature because of differences in pricing systems, use or nonuse of milk production or sales quotas, and trait definitions (Wolfová and Wolf, 2013). The ratio of the marginal weights for milk fat and protein content for Slovak Pinzgau cattle (1:3.8) estimated previously has been based on economic values defined under the production and economic conditions and pricing system relevant in 2003 (Huba et al., 2004). This pricing system differed substantially from the pricing system common for dairy farms in recent years and which was applied in the current study. As stated by Wolfová et al. (2007), use of index weights based on an inappropriate pricing system can strongly decrease the total economic selection response.

Among the remaining growth traits evaluated in our study, mature weight of cows showed a comparatively high relative economic importance, above all in the dairy population (9\%), although with a negative sign on the marginal economic value. This negative economic value was caused by the fact that revenues from heavier culled cows did not cover the higher costs associated with increased energy requirement for cow maintenance. Similar results have been reported by such authors as Fernández-Perea and Jiménez (2004), Keller et al. (2009), and Komlósi et al. (2010). In our study, mature weight of animals was considered to be a separate trait which, to avoid double-counting, could be changed by selection independently of growth rates of young animals (Wolfová and Wolf, 2013). However, correlations among growth traits and the relationship of cow weight to milk yield (in the dairy system) should be taken into account when these traits are included into selection indices (Sölkner et al., 2000; FernándezPerea and Jiménez, 2004), especially for the Pinzgau breed, where high cow weights can have serious implications for pasture surfaces.

Regarding carcass traits, only dressing percentage has been included in the current breeding goal for Slovak Pinzgau cattle (ASPB, 2015). The low proportions of slaughtered animals in both production systems along with low beef prices have resulted in low economic values for all carcass traits in our study as well as in other studies dealing with the Pinzgau breed (Krupová et al., 2009; Krupa et al., 2011). The same situation has been reported for Hungarian and Finnish dairy cattle (Komlósi et al., 2010; Hietala et al., 2014). In Austria (Sölkner et al., 2000) and in Spain (Fernández-Perea and Jiménez, 2004), on the other hand, a strong economic importance (€11.26 per genetic standard deviation of dressing percentage and $€ 6.2$ per dressing percentage) was calculated, and that led to the inclusion of these traits into the selection indices of dual-purpose and beef cattle breeds in those countries.

\section{CONCLUSIONS}

Economic values of traits calculated in this study indicated that the current breeding objective and selection index for Slovak Pinzgau cattle should be redefined. In addition to milk and growth traits, some functional traits (health, fertility, and survival traits) should be included in the breeding objective to reflect the increased interest among customers in animal welfare and quality of dairy farm products while also taking into account the relatively high economic importance of some functional traits. It will also be important, however, to study the expected genetic responses in all of the new traits that are candidates for inclusion into the breeding program for Pinzgau cattle while also taking into account additional costs connected with their measurement or testing. Furthermore, the relative weighting of the current breeding objective traits (milk, growth, and carcass traits) should be examined. Keeping carcass traits within the current breeding goal for the breed does not correspond with the long-term unfavorable situation in the beef market, and so this should be reconsidered.

\section{ACKNOWLEDGMENTS}

The authors thank the Breeding Service of the Slovak Republic for making the data from performance testing available and cattle farmers for providing production and economic data. The authors acknowledge English Editorial Services for editing of the text and Jochen Wolf for helpful comments. The study was funded by project no. QJ1510217 and MZERO0714 of the Czech Republic, a project financed by the Ministry of Agriculture and Rural Development of the Slovak Republic, and the ECOVAplus project ITMS No. 26220120032 implemented under the Operational Programme Research and Development financed by the European Fund for Regional Development. 


\section{REFERENCES}

ASPB (Association of Slovak Pinzgau Breeders). 2015. Chovný ciel'. Accessed Jan. 29, 2015. http://www.pinzgau.sk/chovny-cie-.html.

Bell, M. J., R. J. Eckard, M. Haile-Mariam, and J. E. Pryce. 2013. The effect of changing cow production and fitness traits on net income and greenhouse gas emissions from Australian dairy systems. J. Dairy Sci. 96:7918-7931. http://dx.doi.org/10.3168/jds.2012-6289.

Candrák, J., and I. Lichanec. 2007. Odhad plemenných hodnôt typu v populácii holsteinského plemena na Slovensku. Pages 4-7 in Odhad Plemenných Hodnôt Exteriéru Holsteinského Dobytka na Slovensku. Slovenská holštajnská Asociácia, Ivanka pri Dunaji, Slovakia.

Connor, E. E. 2015. Invited review: Improving feed efficiency in dairy production: Challenges and possibilities. Animal 9:395-408. http://dx.doi.org/10.1017/S1751731114002997.

de Haas, Y., J. J. Windig, N. P. L. Calus, J. Dijkstra, M. de Haan, A. Bannink, and R. F. Veerkamp. 2011. Genetic parameters for predicted methane production and potential for reducing enteric emissions through genomic selection. J. Dairy Sci. 94:6122-6134. http://dx.doi.org/10.3168/jds.2011-4439.

Fernández-Perea, M. T., and R. A. Jiménez. 2004. Economic weights for a selection index in Avileña purebred beef cattle. Livest. Prod. Sci. 89:223-233. http://dx.doi.org/10.1016/j.livprodsci.2004.01.004.

Gonzalez-Recio, O., J. E. Pryce, M. Haile-Mariam, and B. J. Hayes. 2014. Incorporating heifer feed efficiency in the Australian selection index using genomic selection. J. Dairy Sci. 97:3883-3893. http://dx.doi.org/10.3168/jds.2013-7515.

Hietala, P., M. Wolfová, J. Wolf, J. Kantanen, and J. Juga. 2014. Economic values of production and functional traits, including residual feed intake, in Finnish milk production. J. Dairy Sci. 97:1092-1106. http://dx.doi.org/10.3168/jds.2013-7085.

Huba, J., J. Daňo, J. Kica, D. Peškovičová, E. Krupa, and P. Polák. 2004. Ekonomické váhy ukazovatel’ov mliekovej úžitkovosti v produkčnom systéme roku 2003. J. Farm Anim. Sci. 37:119-123.

Kadlečík, O., R. Kasarda, and G. Mészáros. 2008. Inbreeding in purebred Slovak Pinzgau dual-purpose cattle population. Arch. Zootech. 11:21-28.

Kasarda, R., G. Mészáros, O. Kadlečík, E. Hazuchová, V. Šidlová, and I. Pavlík. 2014. Influence of mating systems and selection intensity on the extent of inbreeding and genetic gain in the Slovak Pinzgau cattle. Czech J. Anim. Sci. 59:219-226.

Keller, K., B. Fürst-Waltl, R. Baumung, Z. Fekete, and F. Szabó. 2009 Einfluss der Länge der Weideperiode auf die Betriebsrentabilität und auf die ökonomischen Gewichte von Merkmalen in der Fleischrinderzucht. Zuchtungskunde 81:225-234.

Komlósi, I., M. Wolfová, J. Wolf, B. Farkas, Z. Szendrei, and B. Béri. 2010. Economic weights of production and functional traits for Holstein-Friesian cattle in Hungary. J. Anim. Breed. Genet. 127:143-153. http://dx.doi.org/10.1111/j.1439-0388.2009.00822.x.

Krupa, E., Z. Krupová, M. Oravcová, P. Polák, and J. Tomka. 2011. Economic importance of the traits for Slovak Pinzgau breed reared in dairy and cow-calf system. Agric. Conspec. Sci. 76:255-258.

Krupová, Z., J. Huba, J. Daňo, E. Krupa, M. Oravcová, and D. Peškovičová. 2009. Economic weights of production and functional traits in dairy cattle under a direct subsidy regime. Czech J. Anim. Sci. 54:249-259.

MARD SR (Ministry of Agriculture and Rural Development of the Slovak Republic). 2014. Oznámenie Ministerstva pôdohospodárstva a rozvoja vidieka Slovenskej republiky o sumách sadzieb priamych platieb. Accessed Dec. 5, 2014. http://www.mpsr.sk/sk/index. php?navID $=126$.

Mark, T., W. F. Fikse, E. Emanuelson, and J. Philipsson. 2002. International genetic evaluations of Holstein sires for milk somatic cell and clinical mastitis. J. Dairy Sci. 85:2384-2392.

Pedersen, J., M. K. Sørensen, M. Toivonen, J.-A. Eriksson, and G. P. Aamand. 2008. Report on Economic Basis for a Nordic Total
Merit Index. Nordic Cattle Genetic Evaluation. Accessed May 27, 2015. http://www.nordicebv.info/NR/rdonlyres/B618C0E5FF6F-4D31-8F86-B3CE4A140043/0/NAV_TMI_report_ lastversion_131108.pdf.

Phocas, F., C. Bloch, P. Chapelle, F. Bécherel, G. Renand, and F. Ménissier. 1998. Developing a breeding objective for a French purebred beef cattle selection programme. Livest. Prod. Sci. 57:49-65.

Riecka, Z., R. Kasarda, and J. Candrák. 2008. Analýza utvárania paznechtov vo vzt'ahu $\mathrm{k}$ produkčným a reprodukčným ukazovatel'om. Acta Fytotech. Zootech. 11:73-77.

Sadeghi-Sefidmazgi, A., M. Moradi-Shahrbabak, A. Nejati-Javaremi, S. R. Miraei-Ashtiani, and P. R. Amer. 2011. Estimation of economic values and financial losses associated with clinical mastitis and somatic cell score in Holstein dairy cattle. Animal 5:33-42. http://dx.doi.org/10.1017/S1751731110001655.

Santos, B. F. S., N. McHugh, T. J. Byrne, D. P. Berry, and P. R Amer. 2015. Comparison of breeding objectives across countries with application to sheep indexes in New Zealand and Ireland. J. Anim. Breed. Genet. 132:144-154. http://dx.doi.org/10.1111/ jbg. 12146.

Sölkner, J., J. Miesenberger, A. Willam, C. Fuerst, and R. Baumung. 2000. Total merit indices in dual purpose cattle. Arch. Tierz. 43:597-608.

Tongel', P., and J. Brouček. 2010. Influence of hygienic condition on prevalence of mastitis and lameness in dairy cows. Slovak J. Anim. Sci. 43:95-99.

Vasil', M. 2009. Etiology, course and reduction of incidence of environmental mastitis in the herd of dairy cows. Slovak J. Anim. Sci 42:136-144.

Veerkamp, R. F., G. C. Emmans, A. R. Cromie, and G. Simm. 1995. Variance components for residual feed intake in dairy cows. Livest. Prod. Sci. 41:111-120. http://dx.doi.org/10.1016/03016226(94)00056-D

Williams, Y. J., J. E. Pryce, C. Grainger, W. J. Wales, N. Linden, M. Porker, and B. J. Hayes. 2011. Variation in residual feed intake in Holstein-Friesian dairy heifers in southern Australia. J. Dairy Sci. 94:4715-4725. http://dx.doi.org/10.3168/jds.2010-4015.

Wolf, J., M. Wolfová, and E. Krupa. 2013. User's Manual for the Program Package ECOWEIGHT (C Programs for Calculating Economic Weights in Livestock), Version 6.0.4. Part 1: Programs EWBC (Version 3.0.4) and EWDC (Version 2.2.3) for Cattle. Institute of Animal Science, Prague, Czech Republic. Accessed on May 27, 2015. http://www.vuzv.cz/sites/File/Wolf/ecoweight/6_0_4/ ECOWEIGHT01.pdf.

Wolf, J., M. Wolfová, and M. Štípková. 2010. A model for the genetic evaluation of number of clinical mastitis cases per lactation in Czech Holstein cows. J. Dairy Sci. 93:1193-1204. http://dx.doi. org/10.3168/jds.2009-2443.

Wolfová, M., M. Štípková, and J. Wolf. 2006. Incidence and economics of clinical mastitis in five Holstein herds in the Czech Republic. Prev. Vet. Med. 77:48-64. http://dx.doi.org/10.1016/j. prevetmed.2006.06.002.

Wolfová, M., and J. Wolf. 2013. Strategies for defining traits when calculating economic values for livestock breeding: A review. Animal 7:1401-1413. http://dx.doi.org/10.1017/S1751731113001018.

Wolfová, M., J. Wolf, and J. Hyánek. 1995. Economic weights for beef production traits in the Czech Republic. Livest. Prod. Sci. 43:63-73. http://dx.doi.org/10.1016/0301-6226(95)00007-8.

Wolfová, M., J. Wolf, J. Kvapilík, and J. Kica. 2007. Selection for profit in cattle: I. Economic weights for purebred dairy cattle in the Czech Republic. J. Dairy Sci. 90:2442-2455. http://dx.doi org/10.3168/jds.2006-614.

Zavadilová, L., J. Wolf, M. Štipková, E. Němcová, and J. Jamrozik. 2011. Genetic parameters for somatic cell score in the first three lactations of Czech Holstein and Fleckvieh breeds using a random regression model. Czech J. Anim. Sci. 56:251-260. 